\title{
United States Copper Metal and Scrap Use and Trade Patterns, 1995-2014
}

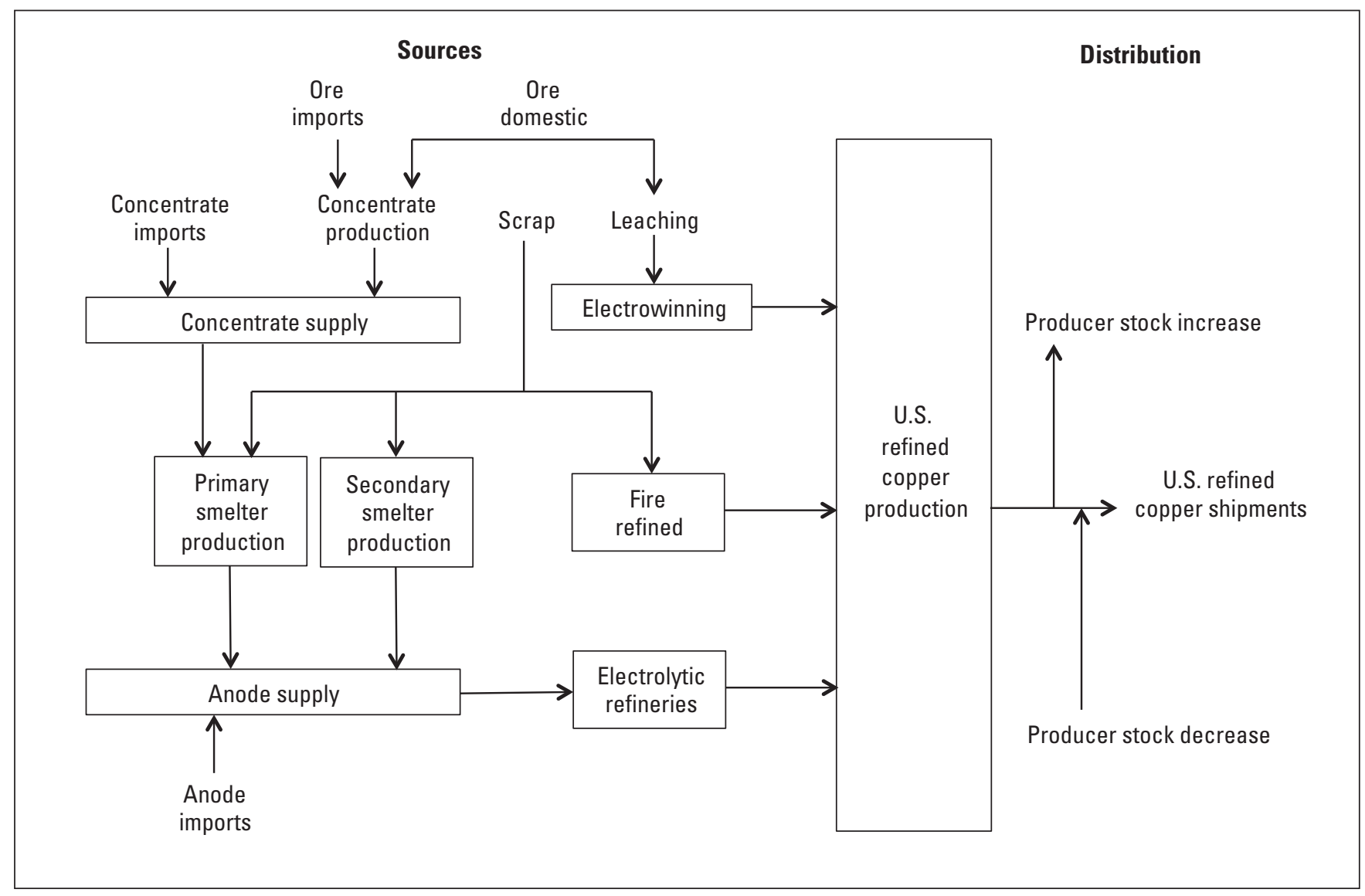

Scientific Investigations Report 2016-5075 
Cover. Generalized flow chart showing the sources and distribution of U.S. refined copper production. 


\section{United States Copper Metal and Scrap Use and Trade Patterns, 1995-2014}

By Thomas G. Goonan

Scientific Investigations Report 2016-5075 


\title{
U.S. Department of the Interior SALLY JEWELL, Secretary
}

\section{U.S. Geological Survey Suzette M. Kimball, Director}

\author{
U.S. Geological Survey, Reston, Virginia: 2016
}

For more information on the USGS - the Federal source for science about the Earth, its natural and living resources, natural hazards, and the environment—visit http://www.usgs.gov or call 1-888-ASK-USGS.

For an overview of USGS information products, including maps, imagery, and publications, visit http://store.usgs.gov.

Any use of trade, firm, or product names is for descriptive purposes only and does not imply endorsement by the U.S. Government.

Although this information product, for the most part, is in the public domain, it also may contain copyrighted materials as noted in the text. Permission to reproduce copyrighted items must be secured from the copyright owner.

Suggested citation:

Goonan, T.G., 2016, United States copper metal and scrap use and trade patterns, 1995-2014: U.S. Geological Survey Scientific Investigations Report 2016-5075, 10 p., http://dx.doi.org/10.3133/sir20165075.

ISSN 2328-031X (print)

ISSN 2328-0328 (online)

ISBN 978-1-4113-4058-9 


\section{Contents}

Abstract
Introduction.
U.S. Copper Metal Supply.12
U.S. Copper Supply for Semi-Manufacturing
U.S. Copper Scrap Trade
Prices
Summary
References Cited

\section{Figures}

1. Line chart showing U.S. production, imports, and exports of refined copper,

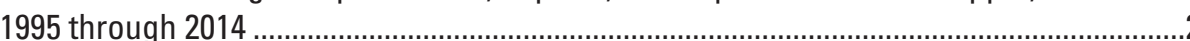

2. Line chart showing U.S. copper-containing scrap flows to manufacturing (production), to exports, and from imports, 1995 through 2014 .........................................

3. Generalized flow chart showing the sources and distribution of U.S. refined copper production.

4. Area and line chart showing U.S. refined copper metal production by source, Chinese refined copper consumption, and U.S. average annual copper metal price, 1995 through 2014.

5. Flow chart showing the sources and distribution of the U.S. copper supply for semi-manufacturing .6

6. Area and line chart showing U.S. copper semi-manufacturing production by source, 1995 through 2014

7. Area and line chart showing the use of old copper scrap in U.S. production, U.S. net exports of copper scrap, and U.S. average annual copper metal price, 1995 through 2014

8. Area and line chart showing U.S. exports of copper scrap, by country, 1995 through 2014

9. Line chart showing U.S. net exports of copper scrap, with and without China included, and U.S. average annual copper metal price, 1995 through 2014

10. Line chart showing constant-dollar prices for copper metal and various types of copper scrap, 1995 through 2014

\section{Table}

1. Annual U.S. refined copper supply, 1995-2014 


\section{Conversion Factors}

International System of Units to Inch/Pound

\begin{tabular}{lcl}
\hline \multicolumn{1}{c}{ Multiply } & By & \multicolumn{1}{c}{ To obtain } \\
\hline kilogram $(\mathrm{kg})$ & 2.205 & pound avoirdupois $(\mathrm{lb})$ \\
kilogram $(\mathrm{kg})$ & 32.1507 & troy ounce \\
metric ton $(\mathrm{t})(1,000 \mathrm{~kg})$ & 1.102 & short ton $(2,000$ pounds $)$ \\
kiloton $(\mathrm{kt})(1,000 \mathrm{t})$ & 1,102 & short ton $(2,000$ pounds $)$ \\
\hline
\end{tabular}

\section{Abbreviation}

Mt million metric tons 


\title{
United States Copper Metal and Scrap Use and Trade Patterns, 1995-2014
}

\author{
By Thomas G. Goonan
}

\section{Abstract}

In 1995, China accounted for 10 percent of world copper consumption (Yue and Lu, 2006; Dove Communications Inc., 2012). By 2014, China accounted for about 49 percent of world copper consumption (World Bureau of Metal Statistics, 2015). This change has affected global copper and copper scrap prices, the sources of copper supply, and U.S. trade of copper-containing materials.

This report considers changes to the copper and copper scrap industries of the United States. For the study period, 1995 through 2014, U.S. refined copper production from all sources (primary and secondary materials) decreased from 2.28 million metric tons (Mt) of copper ${ }^{1}$ to $1.05 \mathrm{Mt}$ (a 54 percent decrease). During the same period, U.S. copper scrap net exports increased from $0.203 \mathrm{Mt}$ to $0.737 \mathrm{Mt}$ (a 263 percent increase and a compound annual growth rate of about 7.0 percent per year). Copper and copper scrap prices (in constant 2014 dollars) rose such that 2014 prices were about 48 percent greater than 1995 prices. From 1995 through 2014, Chinese imports of copper scrap from the United States grew from $0.061 \mathrm{Mt}$ to $0.569 \mathrm{Mt}$ (an increase of $\sim 830$ percent and a compound annual growth rate of $\sim 12.5$ percent per year). In 2011, Chinese imports of U.S. copper scrap peaked at $0.745 \mathrm{Mt}$ of contained copper. In 1995, Chinese imports of U.S. copper scrap accounted for 17 percent of U.S. copper scrap exports. By 2014, Chinese imports accounted for 69 percent of U.S. copper scrap exports (by weight), and Chinese imports of U.S. copper scrap were valued at $\$ 1.45$ billion.

\footnotetext{
${ }^{1}$ Unless stated otherwise, all weight units are in terms of contained copper (the copper content of scrap).
}

\section{Introduction}

Copper-containing products include copper metal, copper alloys, and copper chemicals. All of these are manufactured in the United States from primary raw materials supplemented by significant quantities of secondary materials (recycled scrap). Throughout the study period, 1995-2014, the flows of coppercontaining materials needed for the manufacture of useful copper-containing products changed. Trends for these changes are reported here. For example, U.S. refined copper production in 2014 was less than half of what it was in 1995. Annual refined copper imports more than doubled $(0.429 \text { to } 1.06 \mathrm{Mt})^{2}$ from 1995 through 2000 (partly in response to reduced domestic refined copper production), then, on average, remained relatively level (0.962 Mt) through 2006, thereafter declining by about 5 percent per year (compounded annually) to the 2014 level of $0.620 \mathrm{Mt}$. In terms of percentage, the U.S. share of world refined copper production decreased by a factor of 4 (19 percent to 4.5 percent of world refined copper production over the study period). These salient trends are shown in figure 1.

From 1997 through 2002, the average annual use of old scrap in U.S. refined and alloy copper production decreased by about 72 percent. For the same period, the use of new scrap for the same purpose decreased by about 18 percent. This was a period characterized by closures of both primary smelting and secondary domestic copper production at downstream plants and mills. For the same period, the U.S. export of coppercontaining scrap increased by about 35 percent. Compared to the dynamics in scrap use and trade, U.S. copper-containing

\footnotetext{
${ }^{2}$ All mass units are reported to three significant figures.
} 


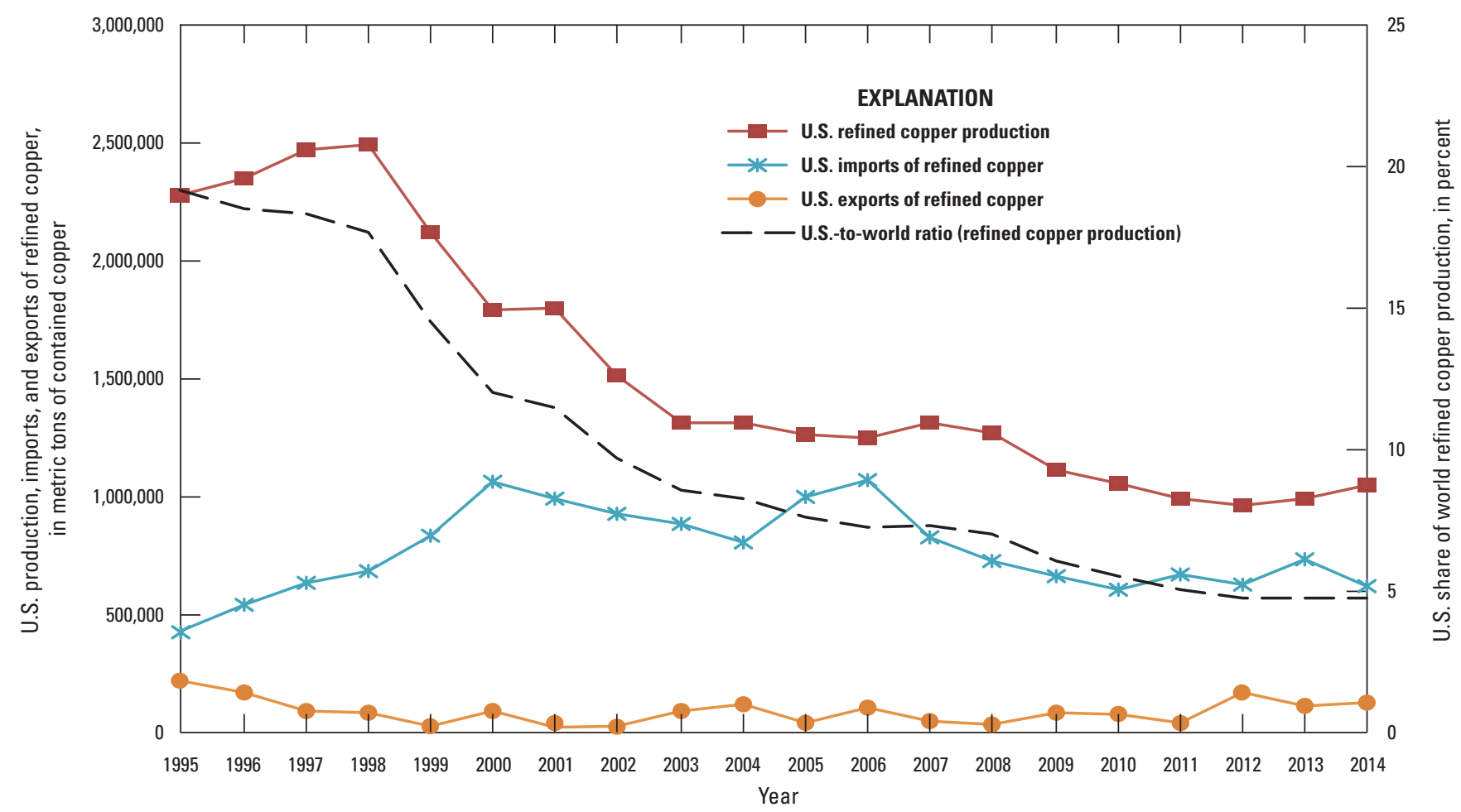

Figure 1. Line chart showing U.S. production, imports, and exports of refined copper, 1995 through 2014. Sources: U.S. Geological Survey (1995-2013); Brininstool (2015a,b); Mark Brininstool, U.S. Geological Survey, unpub. data, 2016.

scrap imports were relatively steady for the entire 1995-2014 study period. The average annual use of new scrap in U.S. production at the primary and secondary level decreased in steps over this study period, as follows: for 1995-2000, the average annual use was $1.02 \mathrm{Mt}$; for 2003-2007, the average annual use was $0.792 \mathrm{Mt}$; and for 2009-2014, the average annual use was $0.638 \mathrm{Mt}$. Since new scrap is basically turnaround material that sustains production levels, the decrease mirrors the reduction in level of production in U.S. plants and mills. These data are shown in figure 2.

\section{U.S. Copper Metal Supply}

Refined copper metal, in the form of cathode (99.99 percent pure copper), is produced from domestic ores and imported materials (ores, concentrates, anodes, and other), with minor augmentation by scrap. Refined copper is produced either by electrolysis of anodes (a product of pyrometallurgical smelting) or by electrowinning of copper from copper-bearing solutions (a product of hydro-metallurgical leaching of domestic ores). Fire-refined copper (99.25 percent pure copper) adds a small amount of refined copper to annual supply. The main components of U.S. refined copper production are shown as a generalized flow diagram in figure 3 and annual contributions to U.S. refined copper production are shown for the study period in figure 4 .
U.S. annual refined copper metal production has continuously decreased (5.5 percent per year, compounded annually) from its study-period peak-year level, $2.49 \mathrm{Mt}$ in 1998, to 1.01 Mt in 2014, a difference of 1.48 Mt. During the same period, Chinese consumption of refined copper increased (15.8 percent per year, compounded annually) from $1.48 \mathrm{Mt}$ in 1998 to $15.4 \mathrm{Mt}$ in 2014 (Yue and Lu, 2006; China Mining Association, 2012; Dove Communications Inc., 2012; and World Bureau of Metal Statistics, 2015).

In 1998, U.S. electrolytically refined copper production was $1.53 \mathrm{Mt}$ using seven primary (concentrate) smelters and three secondary (scrap) smelters to feed seven electrolytic refineries. In 2003, U.S. electrolytically refined copper production was $0.662 \mathrm{Mt}$ (a 15.4 percent per year decrease, compounded annually), and used the facilities of just three primary (concentrate) smelters to feed four electrolytic refineries. From 1998 through 2003, fire-refined copper production decreased (reflecting closure of three facilities) by $0.110 \mathrm{Mt}$, and electrowinning copper production decreased by $0.018 \mathrm{Mt}$.

From 1998 through 2003, total U.S. refined copper production decreased by $1.20 \mathrm{Mt}$, of which about 76 percent was attributable (by a sequence of reduced production ending in closure) to four primary smelters, 13 percent to three secondary smelters, 10 percent to three fire refineries, and 1 percent to three electrowinning refineries. The $1.20 \mathrm{Mt}$ reduction in U.S. refined copper production was partially offset by increased imports of refined copper $(0.199 \mathrm{Mt})$, for a net loss to U.S. refined copper supply of about $0.939 \mathrm{Mt}$. 


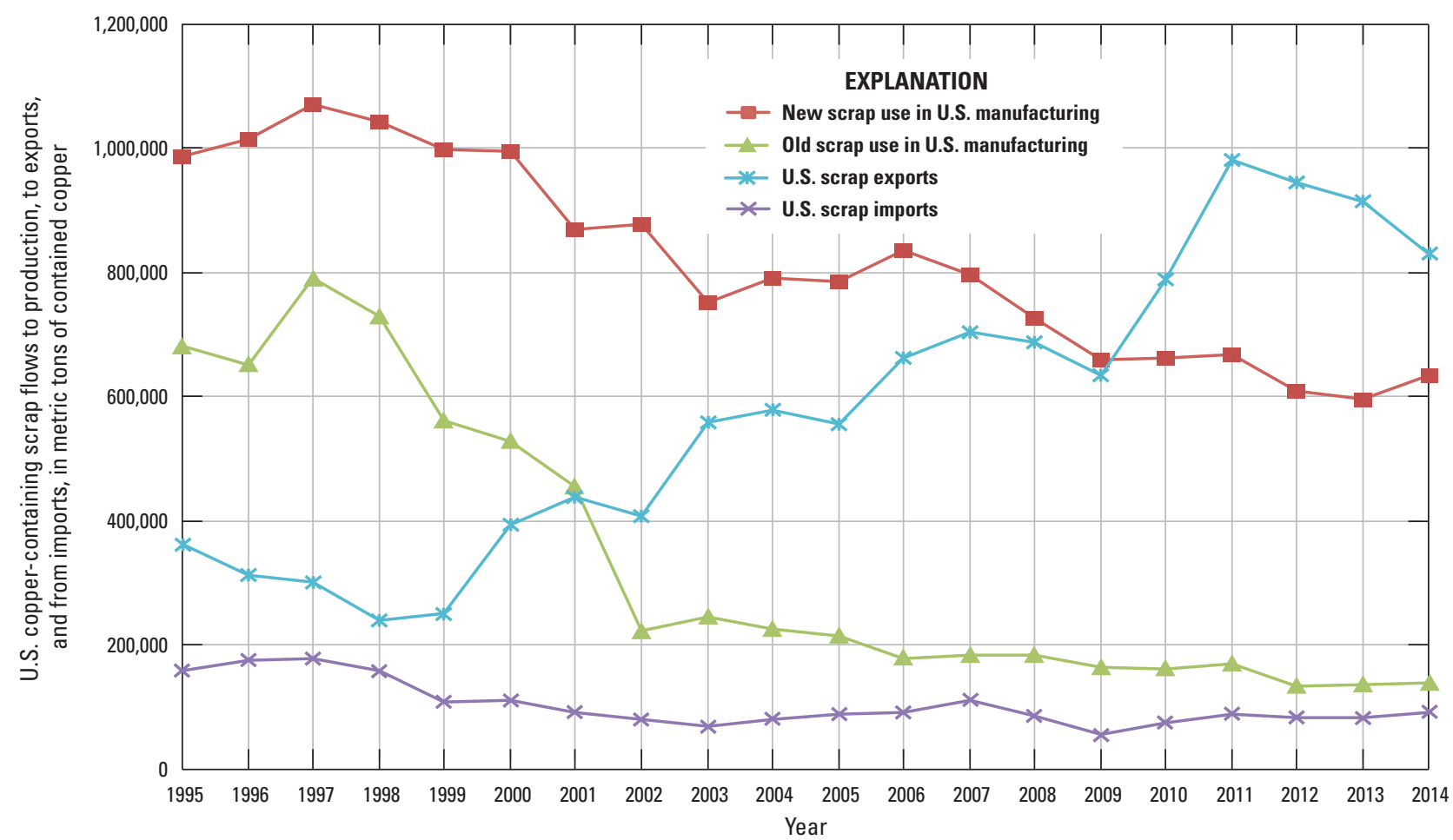

Figure 2. Line chart showing U.S. copper-containing scrap flows to manufacturing (production), to exports, and from imports, 1995 through 2014. Sources: U.S. Geological Survey (1995-2013); Brininstool (2015a,b); Mark Brininstool, U.S. Geological Survey, unpub. data, 2016.

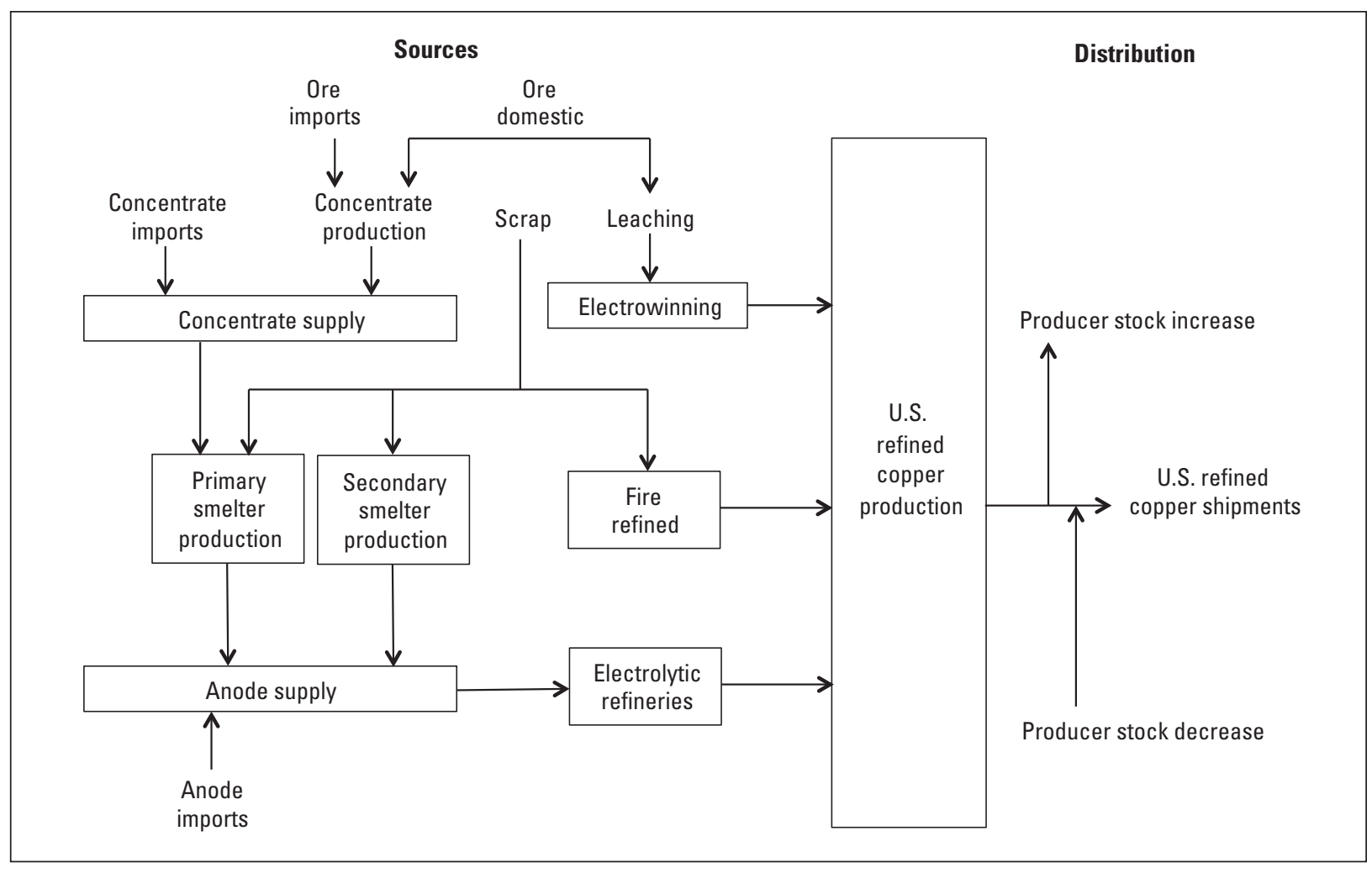

Figure 3. Generalized flow chart showing the sources and distribution of U.S. refined copper production. 


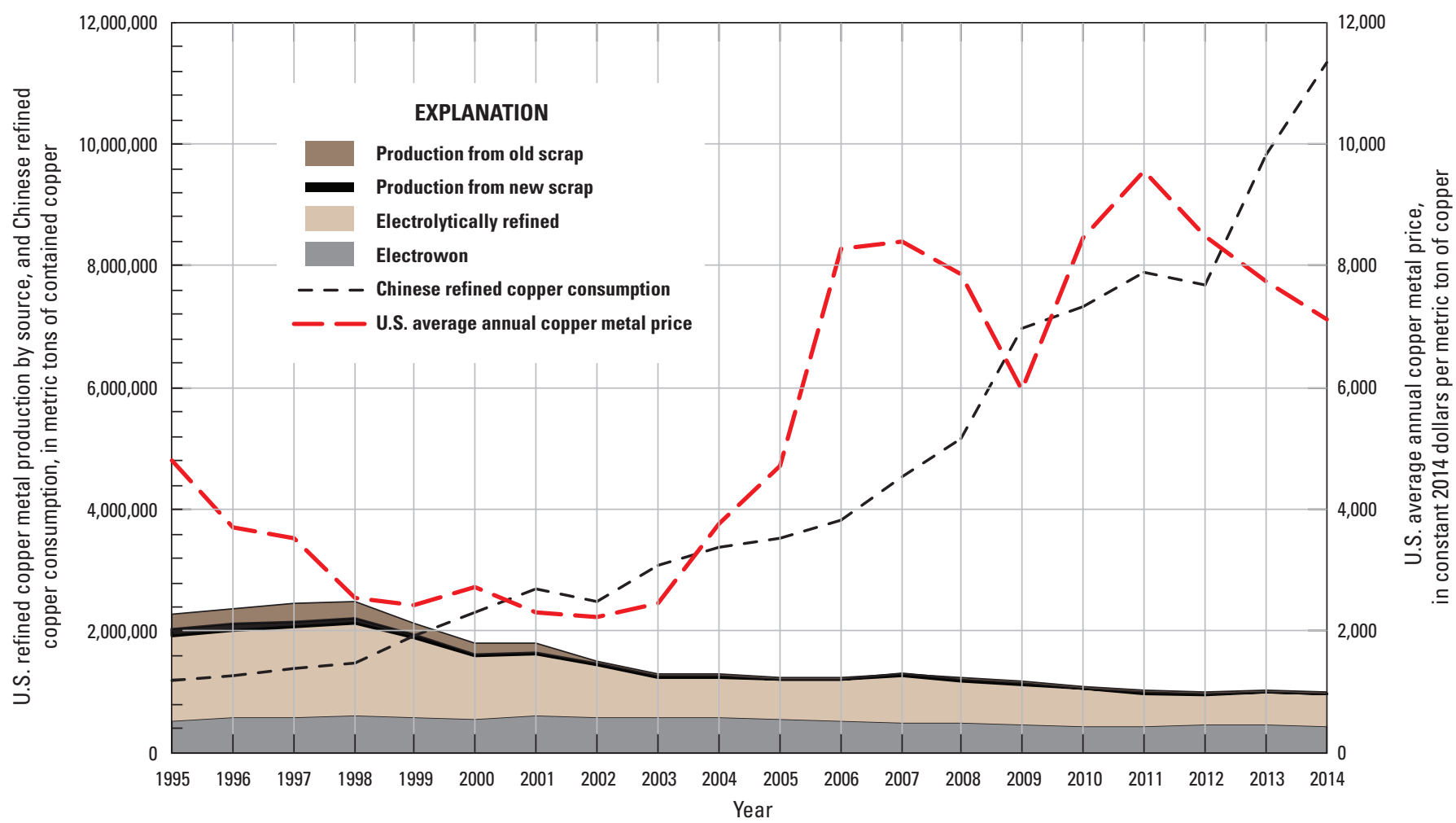

Figure 4. Area and line chart showing U.S. refined copper metal production by source, Chinese refined copper consumption, and U.S. average annual copper metal price, 1995 through 2014. U.S. copper producer prices have been discounted to constant 2014 dollars using the "Historical Consumer Price Index for All Urban Consumers" from the U.S. Department of Labor, Bureau of Labor Statistics (Crawford and others, 2016, p. 72). Other sources: U.S. Geological Survey (1995-2013); Yue and Lu (2006); China Mining Association (2012); Dove Communications Inc. (2012); Brininstool (2015a,b); World Bureau of Metal Statistics (2015); Mark Brininstool, U.S. Geological Survey, unpub. data, 2016.

When supply reduction occurs, it is usually the marginal producers that close. In the U.S. case, lower copper prices and higher production costs associated with lower ore grades, increased energy costs, and pollution control expenses (fines, and capital requirements) were sufficient to force closures (Edelstein, 2002, 2003, 2004, 2005).

From 1998 through 2003, average annual U.S. copper producer prices (in constant 2014 dollars per metric ton) were at their nadir for the study period. From 1998 through 2003, as U.S. refined copper production decreased by $1.20 \mathrm{Mt}$, Chinese annual consumption of refined copper increased by $1.61 \mathrm{Mt}$. From 2003 through 2007, copper metal prices rose, driven up by increased refined copper consumption in China as the Chinese economy rapidly expanded. Prices decreased for the period 2007 through 2009, which was attributable to the global economic downturn. Prices then increased sharply through 2011, again declining through 2014.

\section{U.S. Copper Supply for Semi- Manufacturing}

U.S. refined copper production (previous section), after adjustment for producer inventory changes, becomes refinery shipments. U.S. semi-manufacturers (brass and wire-rod mills, foundries, and chemical plants) use refined copper, copper-containing scrap, and small amounts of other forms of copper to make their products. The refined copper available to semi-manufacturers includes U.S. refined copper shipments less exports, plus imports, adjusted for changes to the inventories of copper at the U.S. warehouses owned by commodity exchanges (COMEX and LME) ${ }^{3}$.

${ }^{3}$ COMEX, Commodity Exchange, Inc., a division of the New York Mercantile Exchange (NYMEX). LME, London Metal Exchange. 
The annual U.S. refined copper supply for the study period is shown in table 1 .

U.S. brass mills, chemical plants, foundries, wire-rod mills, and miscellaneous facilities use refined copper and old scrap to manufacture shapes (pipes, slabs, rods, wire, castings, and other products) composed of copper and copper alloys. New scrap generated by semi-manufacturers is returned to the process and does not add to supply, but rather sustains output levels. Figure 5 shows these generalized flows.

Changes in the average annual semi-manufacturing copper production, 1995-2014, are shown in figure 6. Total average annual use of refined copper and scrap together in U.S. semi-manufacturing (brass and wire-rod mills, foundries, and other facilities) decreased in steps during the study period as follows: 1995-2000, 3.77 Mt; 2001-2007, 3.14 Mt; and
2008-2014, 2.35 Mt. These reductions in semi-manufactured copper production were the result of reductions in the number of domestic facilities operating, due to higher costs and reduced competitiveness. While the number of wire-rod mills remained relatively constant over the study period (15-16), the number of brass mills decreased from 35 to 30 , and the number of foundries and other facilities decreased from 600 to 500 .

Average refined copper usage in domestic semimanufacturing decreased as follows: 1995-2000, 74.2 percent: 2001-2007, 72.7 percent; and 2008-2014, 70.0 percent. The decrease in refined copper usage was offset by increased use of new scrap (indicating better recovery thereof) as follows: 1995-2000, 21.3 percent; 2001-2007, 23.2 percent; and 2008-2014, 25.5 percent. Usage of old scrap for the entire study period remained level at 4.5 percent.

Table 1. Annual U.S. refined copper supply, 1995-2014.

[All values are in million metric tons of contained copper. Values have been rounded to three significant digits. A negative number in the commodity exchange (COMEX and LME) inventory change column indicates an addition to refined copper available to U.S. semi-manufacturers, and a positive number is a subtraction therefrom. Sources: U.S. Geological Survey (1995-2013); Brininstool (2015a,b); Mark Brininstool, U.S. Geological Survey, unpub. data, 2016. Abbreviations: COMEX, Commodity Exchange, Inc. (a division of the New York Mercantile Exchange [NYMEX]); LME, London Metal Exchange]

\begin{tabular}{|c|c|c|c|c|c|c|}
\hline \multirow{2}{*}{ Year } & \multicolumn{3}{|c|}{ U.S. refined copper } & \multirow{2}{*}{$\begin{array}{l}\text { Sum of } \\
\text { COMEX and LME } \\
\text { inventory change }\end{array}$} & \multirow{2}{*}{$\begin{array}{l}\text { Total addition } \\
\text { to U.S. refined } \\
\text { copper supply }\end{array}$} & \multirow{2}{*}{$\begin{array}{l}\text { Refined copper } \\
\text { available for } \\
\text { U.S. semi- } \\
\text { manufacturers }\end{array}$} \\
\hline & Supply & Imports & Exports & & & \\
\hline 1995 & 2.290 & 0.429 & 0.217 & 0.066 & 0.147 & 2.440 \\
\hline 1996 & 2.360 & 0.543 & 0.169 & -0.025 & 0.399 & 2.760 \\
\hline 1997 & 2.440 & 0.632 & 0.093 & 0.147 & 0.392 & 2.830 \\
\hline 1998 & 2.500 & 0.068 & 0.086 & 0.214 & 0.383 & 2.880 \\
\hline 1999 & 2.160 & 0.837 & 0.025 & 0.069 & 0.743 & 2.900 \\
\hline 2000 & 1.790 & 1.060 & 0.093 & -0.232 & 1.200 & 2.990 \\
\hline 2001 & 1.790 & 0.991 & 0.023 & 0.598 & 0.370 & 2.160 \\
\hline 2002 & 1.530 & 0.927 & 0.027 & 0.102 & 0.798 & 2.330 \\
\hline 2003 & 1.310 & 0.882 & 0.093 & -0.373 & 1.160 & 2.470 \\
\hline 2004 & 1.310 & 0.807 & 0.118 & -0.511 & 1.200 & 2.510 \\
\hline 2005 & 1.260 & 1.000 & 0.040 & -0.072 & 1.030 & 2.290 \\
\hline 2006 & 1.230 & 1.070 & 0.106 & 0.100 & 0.864 & 2.090 \\
\hline 2007 & 1.320 & 0.083 & 0.051 & -0.032 & 0.810 & 2.130 \\
\hline 2008 & 1.250 & 0.724 & 0.037 & 0.067 & 0.620 & 1.870 \\
\hline 2009 & 1.160 & 0.664 & 0.081 & 0.232 & 0.351 & 1.510 \\
\hline 2010 & 1.100 & 0.605 & 0.076 & -0.030 & 0.560 & 1.660 \\
\hline 2011 & 1.020 & 0.670 & 0.040 & 0.022 & 0.607 & 1.630 \\
\hline 2012 & 0.991 & 0.630 & 0.169 & -0.181 & 0.642 & 1.630 \\
\hline 2013 & 1.040 & 0.734 & 0.111 & 0.016 & 0.607 & 1.640 \\
\hline 2014 & 1.020 & 0.620 & 0.127 & -0.074 & 0.567 & 1.580 \\
\hline
\end{tabular}




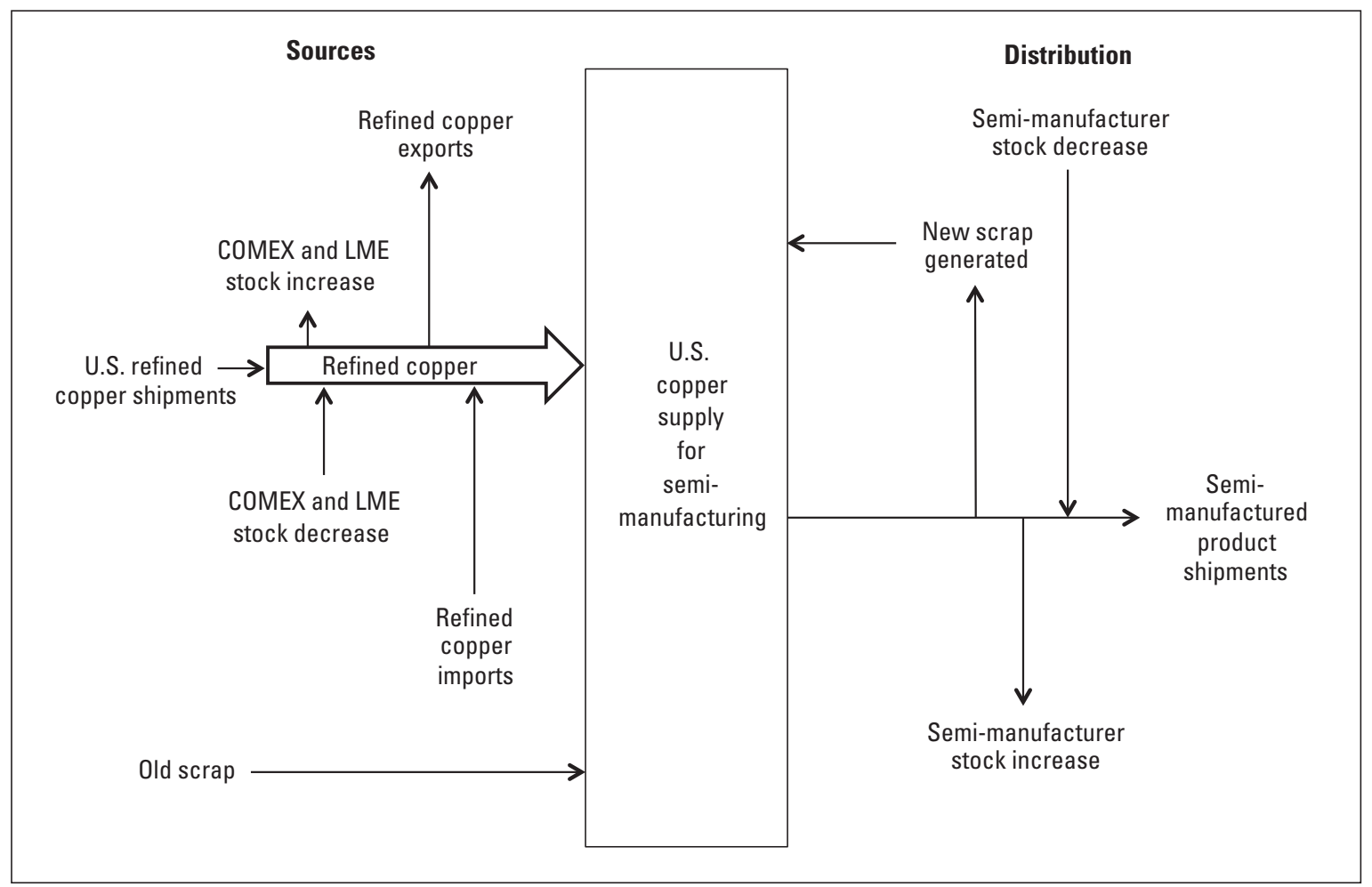

Figure 5. Flow chart showing the sources and distribution of the U.S. copper supply for semi-manufacturing.

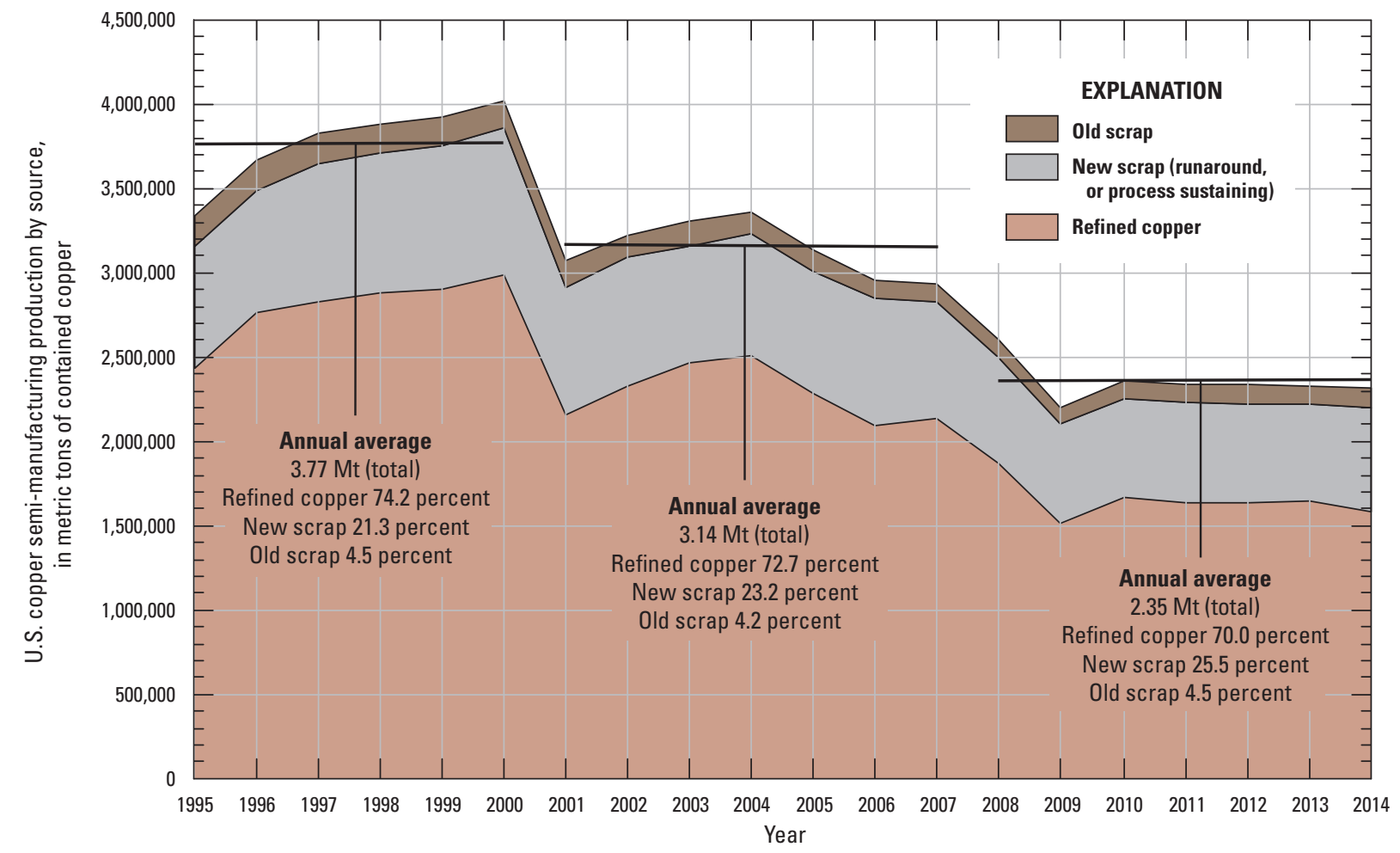

Figure 6. Area and line chart showing U.S. copper semi-manufacturing production by source, 1995 through 2014. Values for annual averages reported within the graphic are in million metric tons (Mt) of contained copper. Sources: U.S. Geological Survey (1995-2013); Brininstool (2015a,b); Mark Brininstool, U.S. Geological Survey, unpub. data, 2016. 


\section{U.S. Copper Scrap Trade}

In general, scrap trade is dominated by old scrap recovered from post-consumer sources. New scrap is generated and returned to use domestically. The United States is, and has been for the entire study period, a net exporter of old copper scrap. Most U.S. imports of copper scrap are sourced from Canada, Mexico, and Caribbean and South American countries.

U.S. trade in old copper scrap has changed along with the changes in old copper scrap usage in the production of U.S. refined copper and mill products. Figure 7 shows the distribution of U.S. old copper scrap supply among usage in domestic production and trade as net exports, with the U.S. price of copper for context.

Figure 7 shows that old scrap usage for U.S. domestic copper production decreased sharply from 1997 (period peak, $0.790 \mathrm{Mt}$ ) through $2002(0.224 \mathrm{Mt})$. During this 5-year period, major scrap users either reduced operations or closed (four primary smelters, four secondary smelters, three fire refiners, and five brass mills) under pressure of low prices and high costs (Edelstein, 2002, 2003, 2004, 2005). From 1999 through 2012, scrap suppliers increasingly exported old scrap. Higher copper prices from 2009 through 2012 caused the collection of additional scrap for export, of which a high percentage went to China. With lower prices in 2013 and 2014, less old scrap was collected and exported.

Figure 8 shows the quantities and destinations for U.S. copper scrap exports for the study period. From 1995 through 2014, U.S. copper scrap exports increased from 0.375 to $0.830 \mathrm{Mt}$ of contained copper, a growth rate of 4.3 percent per year, compounded annually. The subtotal of U.S. exports of copper scrap to countries other than China was relatively stable for the study period.

The importance of U.S. exports of copper scrap to China is clearly seen by the placement of the China data at the top of the area chart in figure 8. Virtually all of U.S. copper scrap export growth was attributable to Chinese imports thereof, which increased from $0.061 \mathrm{Mt}$ of contained copper in 1995 to $0.569 \mathrm{Mt}$ of contained copper in 2014, a 12.5 percent-peryear growth rate, compounded annually. From 1998 onward, China's demand for copper was much greater than could be fulfilled from primary smelting, so China was forced to go heavily into the world scrap market, thereby driving up copper scrap prices (Yue and Lu, 2006). China's consumption of copper, including that sourced from scrap, totaled 49 percent

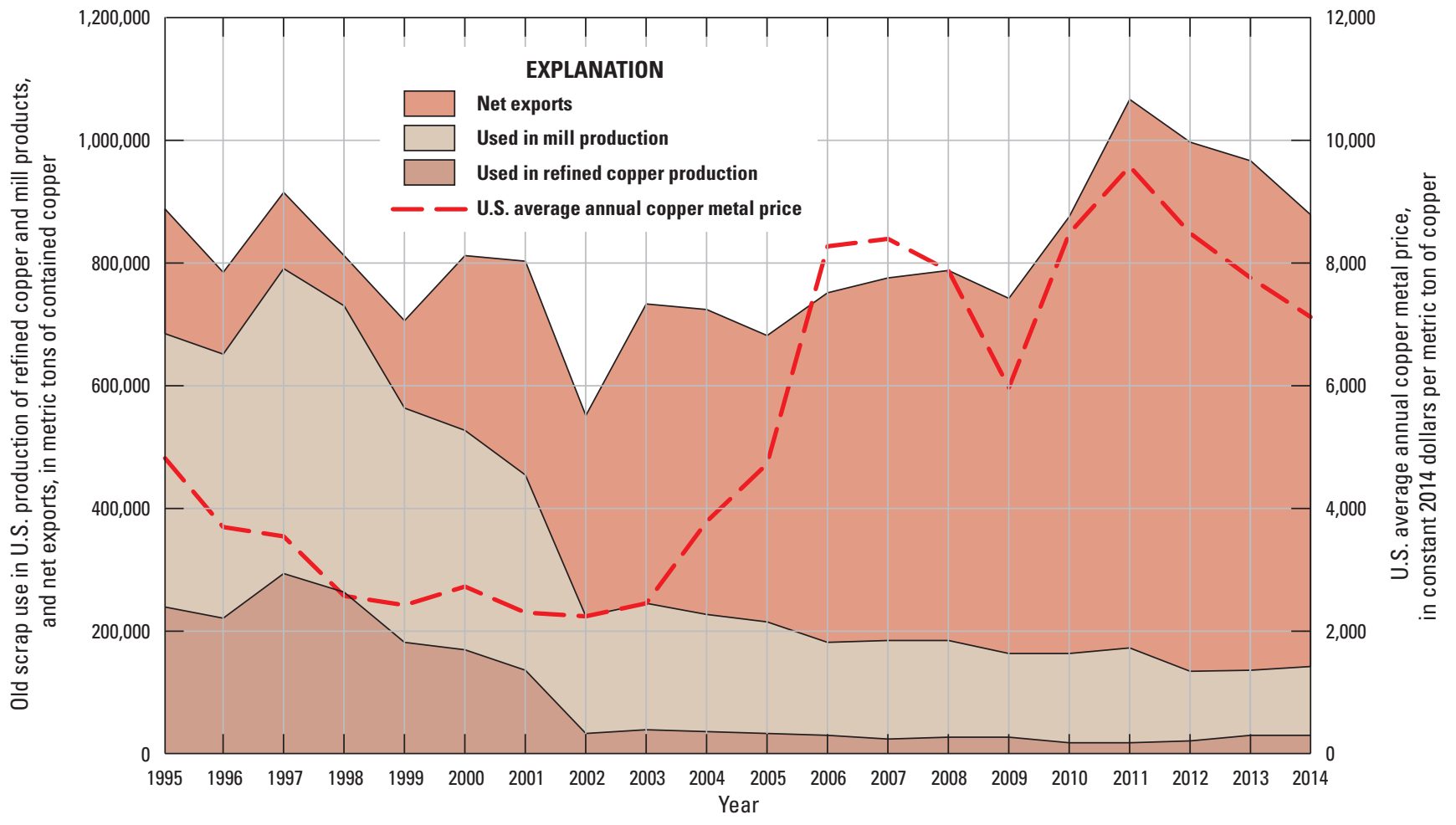

Figure 7. Area and line chart showing the use of old copper scrap in U.S. production, U.S. net exports of copper scrap, and U.S. average annual copper metal price, 1995 through 2014. U.S. average annual copper metal price is based on producer prices that have been discounted to constant 2014 dollars using the "Historical Consumer Price Index for All Urban Consumers" from the U.S. Department of Labor, Bureau of Labor Statistics (Crawford and others, 2016, p. 72). Production data from U.S. Geological Survey (1995-2013); Brininstool (2015a,b); Mark Brininstool, U.S. Geological Survey, unpub. data, 2016. 
United States Copper Metal and Scrap Use and Trade Patterns, 1995-2014

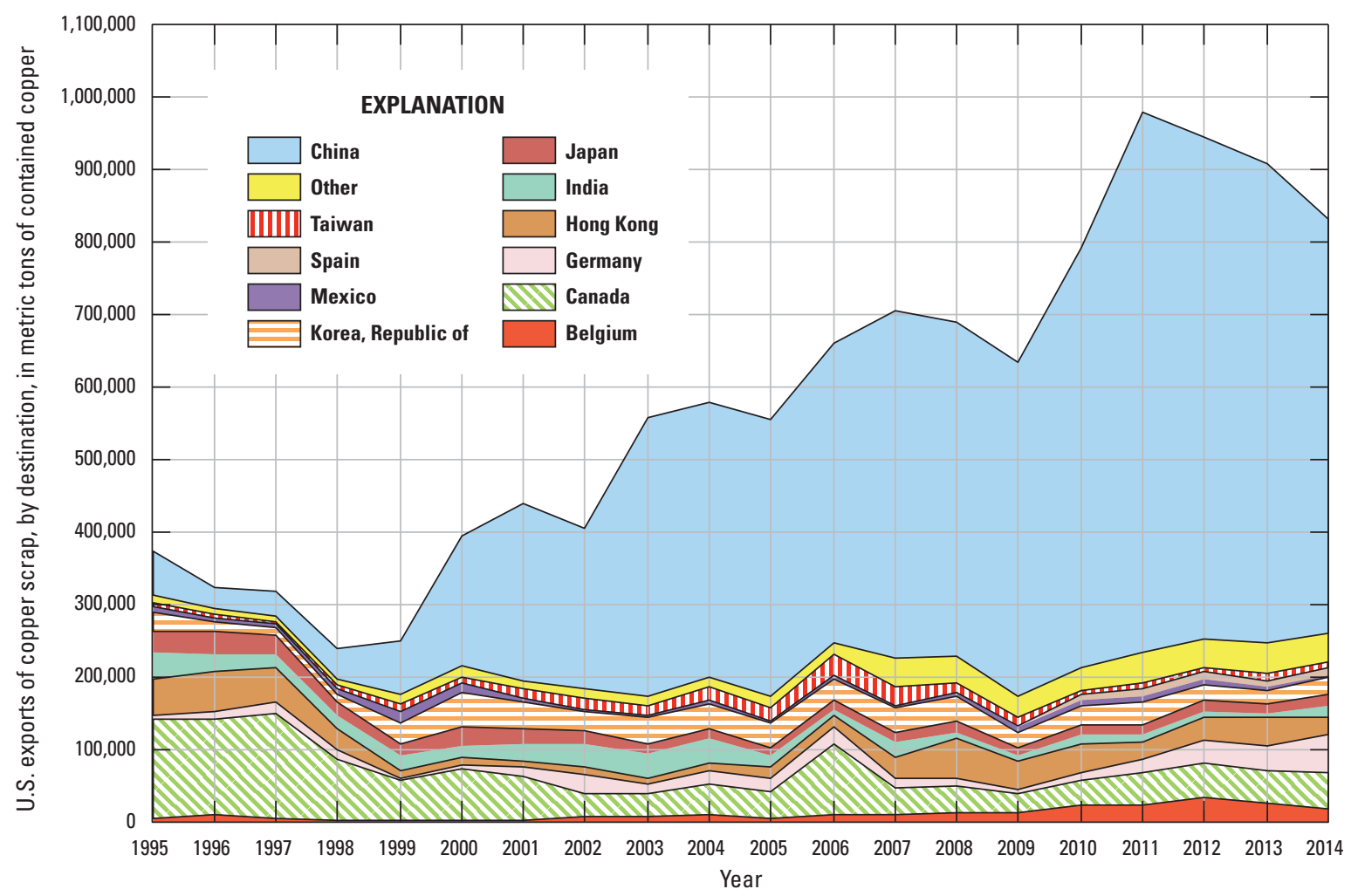

Figure 8. Area and line chart showing U.S. exports of copper scrap, by country, 1995 through 2014. Sources: U.S. Geological Survey (1995-2013); Brininstool (2015a,b); Mark Brininstool, U.S. Geological Survey, unpub. data, 2016.

of global production in 2014 (World Bureau of Metal Statistics, 2015). The trade-value of U.S. copper scrap exports in 2014 was $\$ 3.48$ billion, and the trade-value of the Chinese fraction was $\$ 2.10$ billion, or 60 percent.

In figure 9, U.S. net exports of copper scrap are shown with and without China included, and copper price is added.

Based on the endpoints of the linear trendline for U.S. net exports (China excluded), U.S. net exports to the rest of the world (the greater part of which are other Asian countries) increased 2.9 percent per year, compounded annually, over the study period. After 1998, Chinese imports of U.S. copper scrap (and therefore U.S. net exports [China included]) increased rapidly, and, as shown in figure 7, compensated for reductions in U.S. usage of old scrap for domestic production of refined copper and mill products. Essentially, a large part of the process of adding value to copper scrap through manufacturing was transferred from the United States to China. Regardless of the location of scrap value-enhancement, Chinese demand for copper drove copper metal prices from a year-2002 low of $\$ 2,230$ (constant 2014 dollars per metric ton of copper) to a year-2011 high of $\$ 9,570$ (constant 2014 dollars per metric ton of copper), a 4.3-fold increase. From 2011 through 2014, copper prices decreased to $\$ 7,120$ (constant 2014 dollars per metric ton of copper).

\section{Prices}

Throughout this report, the price of copper metal (U.S. producer) has appeared in the graphics, even when the subject was scrap. Figure 10 shows the relationship of copper scrap prices (brass mill, refiners', and New York dealers' buying) to the copper metal price.

Figure 10 demonstrates that the prices for copper scrap are closely linked to the price of copper metal, such that use of the copper metal price throughout this report was warranted. Copper market supply and demand factors determine the price of copper and the price of copper scrap. The correlation is strongest for high-quality (clean, high copper content) scrap, but holds also for lower quality scrap. 


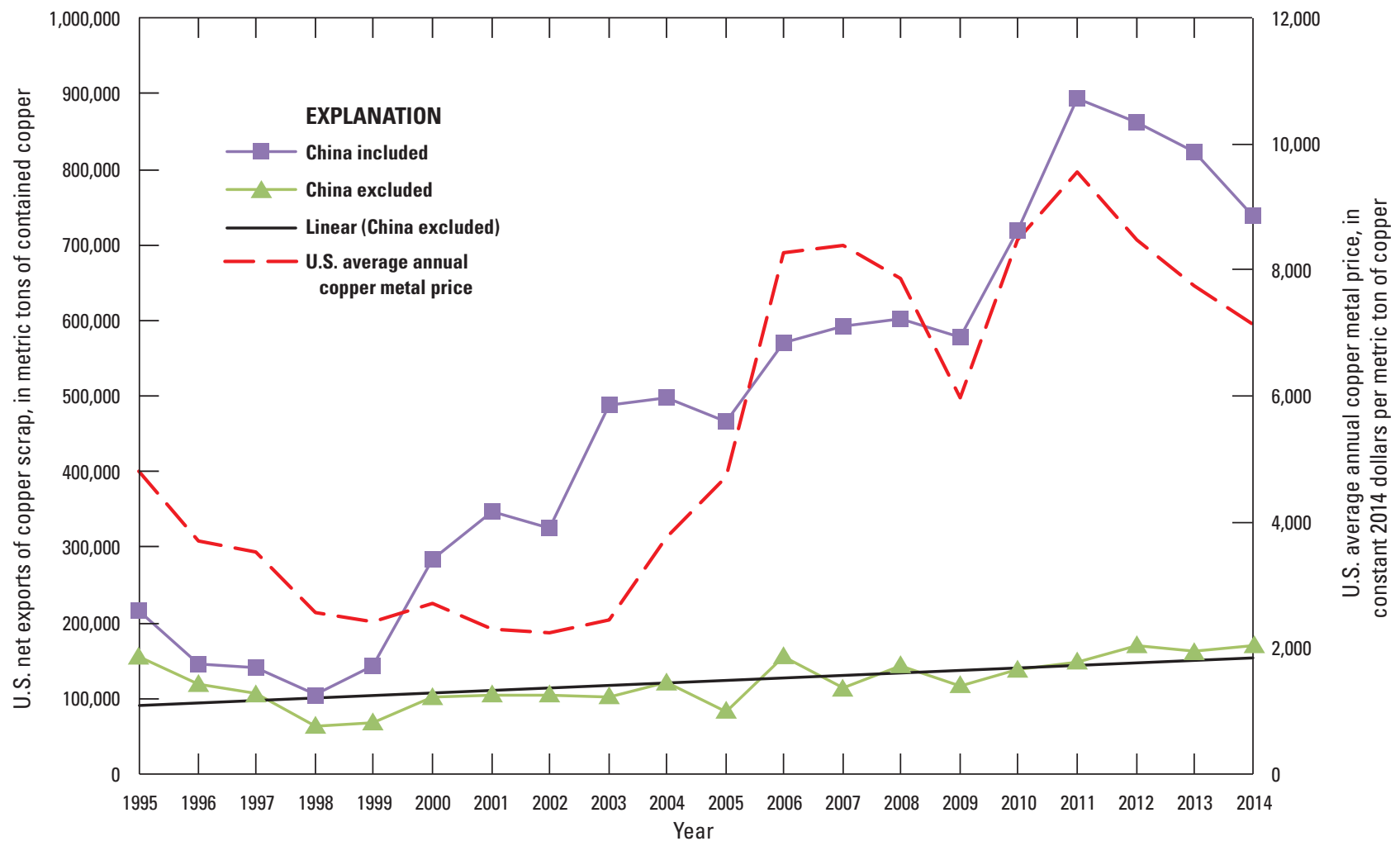

Figure 9. Line chart showing U.S. net exports of copper scrap, with and without China included, and U.S. average annual copper metal price, 1995 through 2014. U.S. copper producer prices have been discounted to constant 2014 dollars using the "Historical Consumer Price Index for All Urban Consumers" from the U.S. Department of Labor, Bureau of Labor Statistics (Crawford and others, 2016, p. 72). Production data from U.S. Geological Survey (1995-2013); Brininstool (2015a,b); Mark Brininstool, U.S. Geological Survey, unpub. data, 2016.

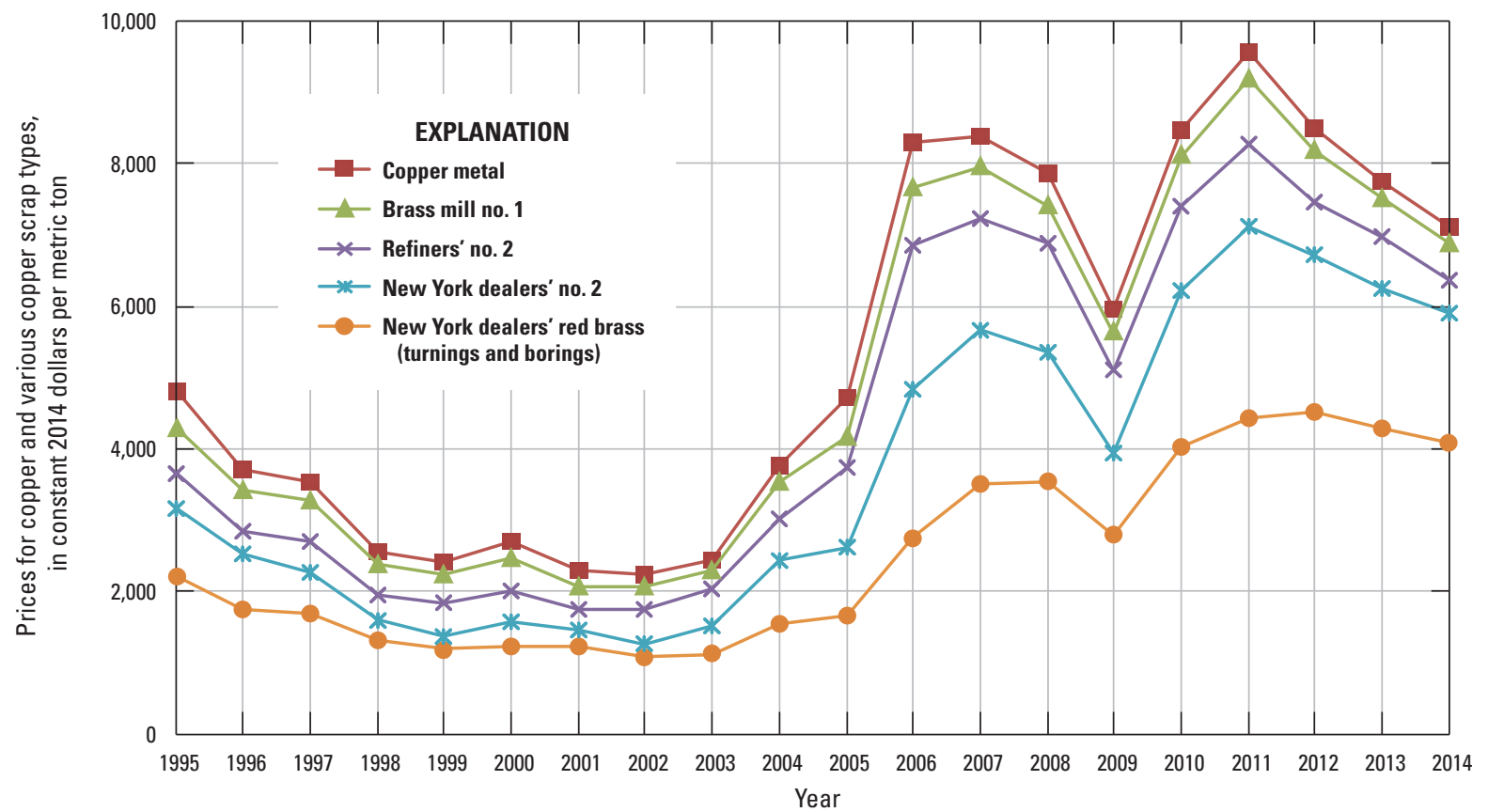

Figure 10. Line chart showing constant-dollar prices for copper metal and various types of copper scrap, 1995 through 2014. U.S. copper producer prices, as well as scrap prices as reported by American Metal Market, have all been discounted to constant 2014 dollars using the "Historical Consumer Price Index for All Urban Consumers" from the U.S. Department of Labor, Bureau of Labor Statistics (Crawford and others, 2016, p. 72). Production data from U.S. Geological Survey (1995-2013); Brininstool (2015a,b); Mark Brininstool, U.S. Geological Survey, unpub. data, 2016. 


\section{Summary}

The worldwide demand for copper has increased, and much of that demand (49 percent in 2014) originated from China as its economy became increasingly industrialized to service both Chinese domestic consumption and Chinese exports of assembled products. China's demand for the world's copper resources has driven up copper prices. The United States, with its mature industrial economy and its shrinking refined copper industry, has been supplying increasingly more scrap to the world, mainly to China. Although the U.S. continues to fill part of its domestic demand for finished copper products by means of domestic production, it is acquiring copper-containing products to a greater degree from foreign sources, including China. Chinese demand for U.S. scrap decreased from its high in 2011 of $0.745 \mathrm{Mt}$ of contained copper to $0.569 \mathrm{Mt}$ in 2014, a 24 percent decrease. For the same period, the copper metal price decreased from $\$ 9,570$ to $\$ 7,120$ (constant 2014 dollars per metric ton of copper), a 26 percent decrease. If Chinese demand for copper falters further, there could be an additional oversupply of copper scrap, and prices could continue to fall.

\section{References Cited}

Brininstool, Mark, 2015a, Copper [advance release], in Metals and minerals: U.S. Geological Survey Minerals Yearbook 2012, v. I, p. 20.1-20.27, accessed April 1, 2016, at http://minerals.er.usgs.gov/minerals/pubs/commodity/ copper/myb1-2012-coppe.pdf.]

Brininstool, Mark, 2015b, Copper [advance release], in Metals and minerals: U.S. Geological Survey Minerals Yearbook 2013, v. I, p. 20.1-20.29, accessed April 1, 2016, at http://minerals.er.usgs.gov/minerals/pubs/commodity/ copper/myb1-2013-coppe.pdf.]

China Mining Association, 2012, China 2013 refined copper consumption to rise 5.5 percent-Antaike: China Mining Association, October 31, 2012, accessed February 10, 2015, at http://en.chinamining.com.cn/ News/2012-10-31/1351653346d59632.html.

Crawford, Malik, Church, Jonathan, and Akin, Bradley, eds., 2016, CPI detailed report data for February 2016: U.S. Department of Labor, Bureau of Labor Statistics, 117 p., accessed April 1, 2016, at http://www.bls.gov/cpi/ cpid1602.pdf. [See table 24 on p. 72.]
Dove Communications Inc., 2012, China copper consumption trends (1): Online graphic accessed February 10, 2014, at http://www.dovecommunications.ca/copper-promiseslong-term-value-for-commodities-investors/china-copperconsumption-trends- $1 /$

Edelstein, D.L., 2002, Copper, in Metals and minerals: U.S. Geological Survey Minerals Yearbook 2000, v. I, p. 23.1-[23.25]. [Also available at http://minerals.er.usgs.gov/ minerals/pubs/commodity/copper/240400.pdf.]

Edelstein, D.L., 2003, Copper, in Metals and minerals: U.S. Geological Survey Minerals Yearbook 2001, v. I, p. 22.1-[22.27]. [Also available at http://minerals.er.usgs.gov/ minerals/pubs/commodity/copper/coppmyb01.pdf.]

Edelstein, D.L., 2004, Copper, in Metals and minerals: U.S. Geological Survey Minerals Yearbook 2002, v. I, p. 22.1-22.28. [Also available at http://minerals.er.usgs.gov/ minerals/pubs/commodity/copper/coppemyb02r.pdf.]

Edelstein, D.L., 2005, Copper, in Metals and minerals: U.S. Geological Survey Minerals Yearbook 2003, v. I, p. 21.1-21.27. [Also available at http://minerals.er.usgs.gov/ minerals/pubs/commodity/copper/coppemyb03.pdf.]

U.S. Geological Survey, 1995-2013, Copper, in Metals and minerals: U.S. Geological Survey Minerals Yearbook, 1994-2011, v. I [variously paged], accessed April 1, 2016, at http://minerals.usgs.gov/minerals/pubs/commodity/copper/.

World Bureau of Metal Statistics, 2015, January to December 2014 metal balances: World Bureau of Metal Statistics News and Announcements Web site, accessed March 21, 2016, at http://www.world-bureau.com/readnews.asp?id $=19$.

Yue, Qiang, and Lu, Zhong-wu, 2006, An analysis of contemporary copper recycling in China: The Chinese Journal of Process Engineering, v. 6, no. 4, August 2006, p. 683-690. [Also available at http://www.jproeng.com/qikan/manage/ wenzhang/206530.pdf.] 
Manuscript approved May 27, 2016

Prepared by the USGS Science Publishing Network Reston Publishing Service Center Edited by James R. Estabrook Illustrations and layout by Caryl J. Wipperfurth Web support by Angela E. Hall

For additional information, please contact:

Director, National Minerals Information Center

U.S. Geological Survey

12201 Sunrise Valley Drive

988 National Center

Reston, VA 20192

Email: nmicrecordsmgt@usgs.gov

Or visit the USGS Minerals Information Web site at http://minerals.usgs.gov/minerals/ 


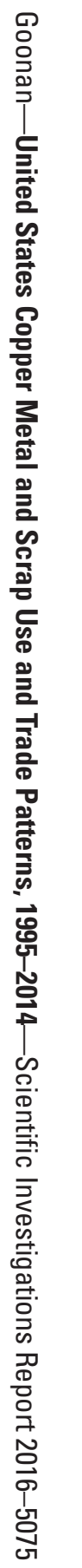

